\title{
Dialogic Teaching during Cooperative Inquiry-Based Science: A Case Study of a Year 6 Classroom
}

\author{
Robyn M. Gillies $(\mathbb{D}$ \\ School of Education, The University of Queensland, Brisbane 4072, Australia; r.gillies@uq.edu.au
}

Received: 28 September 2020; Accepted: 9 November 2020; Published: 12 November 2020

check for updates

\begin{abstract}
Teachers play a critical role in promoting dialogic interaction in their students. The purpose of this case study was to investigate how one very effective teacher taught two, cooperative, inquiry-based science units to her Year 6 class. In particular, the case study focused on how she used different discourses to capture students' curiosity in the inquiry-based tasks, provided hands-on activities to enable them to test out their hypotheses and develop explanations for what they found in order to help them become more scientifically literate and have a broader understanding of the role of science in the world in which they live. The results showed that the students engaged constructively with their peers on the inquiry group tasks; they used the correct scientific language to discuss phenomena, make claims, and compared findings. Furthermore, they became more adept at expressing their opinions and providing explanations and justifications for the 'scientific' positions they had adopted across the six inquiry-based science lessons; core cognitive practices that support learning. This case study highlights the importance of utilizing both authoritative and dialogic discourse to challenge and scaffold students' thinking to support enhanced understandings and reasoned argumentation during inquiry-based science. This case study fills a gap in the literature on how teachers can utilize different communicative approaches during inquiry-based science units to promote student engagement and learning.
\end{abstract}

Keywords: cooperative learning; collaboration; inquiry-based science; discourse; dialogue

\section{Introduction}

Teachers play a pivotal role in inducting students into ways of thinking and reasoning by making explicit how to express ideas, seek assistance, contest different propositions, and reason cogently [1]. It is well known that students learn when they have opportunities to interact with others where they actively listen to what others have to say, reflect on different propositions, present ideas and information, and, in turn, learn to incorporate different concepts and perspectives into their own understandings. However, such interactions do not happen without modelling and guidance from the class teacher who must construct learning situations where students have opportunities to learn the language of science.

Through modelling and guidance, students learn to better understand how different scientific practices of investigation can be undertaken. Such practices involve thinking like scientists, so students learn to be more meta-cognitive and self-reflective in the feedback they provide to their peers. When this occurs, Herrenkohl, Tasker, and White [2] found students were better able to link their hypotheses, scientific investigations, and data analyses to more coherent accounts of their investigations. Furthermore, they demonstrated positive gains on an individually administered follow-up inquiry test and a group project score that was administered pre- and post-intervention, adding credence to the importance of teaching students how to dialogue together. In fact, Chinn et al. [3] argue that there is a large volume of research that demonstrates that when students participate in inquiry-based 
science, such experiences lead to positive gains in students' explanatory conceptions and reasoning competencies; core cognitive practices that support student learning.

\subsection{Dialogic Teaching and Learning}

Harnessing the power of talk to stimulate and promote students' thinking and learning requires a special type of teaching commonly referred to as dialogic teaching. Dialogic teaching involves five key principles: It is collective and involves the teacher and students discussing learning tasks together in order to clarify concerns and promote understandings; it is reciprocal where the teacher and students present ideas, consider alternative perspectives, and work together to clarify issues; it is supportive enabling students to share their ideas in the context of an environment that respects the ideas of others; it is cumulative in that both the teacher and students build on each other's ideas to develop cogent lines of inquiry; and it is purposeful with the teacher structuring the discussion with a specific educational purpose [4].

When teachers engage in dialogic teaching with their students, Alexander [5] notes, there is more talk about how the discussion will proceed, including the ground rules to be followed. Teachers' questions are often more open and purposeful, enabling students to contribute to the discussion in a more meaningful way. Additionally, students are encouraged to speculate, think aloud, and help each other with both students and teacher building on each other's ideas as they develop "coherent lines of thinking and enquiry" ([6], p. 8). Boyd and Markarian [7] noted that dialogic teaching is evident when teachers use a tone of voice that is conversational, they listen to what others have to say, and encourage students to elaborate on their ideas or questions.

Teaching and learning in the dialogic classroom, Reznitskaya and Gregory [8] argue is characterized by authority over the content and form of discussion shared among group members; questions are open and more divergent and designed to promote meaningful inquiries; teachers provide students with constructive feedback; and students take on key responsibilities for the flow of the discussion. This includes managing turns so all students have opportunities to participate, ask questions, critique others' answers, introduce new topics, and suggest changes to processes of the discussion [8]. Furthermore, students are encouraged to explain their thinking as they work collaboratively with others to co-construct new knowledge and mutual understandings. Gillies [9] reported that when these conditions exist, students are more likely to engage in dialogic exchanges that support enhanced disciplinary knowledge and reasoned argumentation.

Alexander [10] reported on a randomized control trial of a dialogic teaching intervention involving 5000 Year 5 students and 208 teachers across four large cities in the United Kingdom. The intervention was implemented for 20 weeks and involved a cyclic program of planning, goal setting, and review to encourage teachers to extend their own and their students' repertoires of classroom talk to promote dialogue and argumentation. An independent follow-up evaluation of the program indicated that students in the intervention groups were two months ahead of their peers in the control groups on standardized tests of English, mathematics, and science. Similarly, Howe, Hennessy, Mercer, Vrikki, and Wheatley [11], in a large study of 72 demographically diverse classrooms of students, aged 10-11 years, studying mathematics, literacy, and science, found that as long as students engaged extensively in seeking or providing elaborations and challenging others' previous contributions, these categories of language were found to be positively associated with curriculum mastery. Furthermore, elaborations were positively associated with positive attitudes towards learning.

Garcia-Carrion, deAguileta, Padros, and Ramis-Salas [12], in a review of the social impact of dialogic teaching and learning noted that there is accumulated evidence from small and large-scale studies that dialogic teaching contributes to academic achievement and social cohesion, providing children, regardless of their origin, culture, or background with the same opportunities to participate in dialogic spaces that promote their learning and development.

Others who have investigated the role of different types of talk in classrooms are Scott and Mortimer [13] who developed a tool for analyzing the different forms and functions of discursive 
interactions in high school science classrooms. One form of interaction that is particularly prominent is the interactive and dialogic approach where the teacher actively listens to students' ideas and seeks to explore and elicit their ideas further by asking questions that demonstrate a genuine interest in the issue under discussion. A second form of interaction is the authoritative and interactive approach where the teacher is primarily focused on presenting a scientific point of view and leads the students through a series of questions and answers designed to clarify that point of view. Scott, Mortimer, and Aguiar [14] argued that shifts between these styles of interacting are an inevitable part of teaching science as the authoritative approach is often used to introduce new ideas while the dialogic provides opportunities to explore these ideas further. In a study of two secondary science classrooms, Bosser and Lindahl [15] found that in managing classroom discussions, the teachers needed to alternate between both authoritative and dialogic talk, making specific use of each, as well as interactive and non-interactive communicative approaches. This was particularly important when the teacher needed to ensure that students were provided with opportunities to investigate the complexity of an issue by using an interactive/dialogic-fixed end approach (a guided authoritative approach) as well as being responsive to different perspective presented during a discussion (dialogic/interactive approach). In short, Bosser and Lindahl posited that no specific communicative approach is more appropriate than another and teachers need to consider their choices in relation to the specific goals of their teaching.

In summary, studies by Alexander [4,5,10], Boyd and Markarian [7], Garcia-Carrion [12], Gillies [1], Reznitskaya and Gregory [8], and Wolfe and Alexander [9] highlight the importance of dialogic teaching where students are actively engaged in meaningful discussions with each other as they interrogate a topic, explain their thinking, and work constructively together to construct new understandings and conceptions. Scott and Mortimer [13] and Scott, Mortimer, and Aguiar [14] argued that in such classrooms, teachers need to be very adept at using language that not only builds on students' ideas (interactive and dialogic approach) but also enables the teacher to present and model the canonical ways of reasoning in science (authoritative and interactive approach) relevant to the topic under discussion. Bosser and Lindahl [15] noted that the type of communicative approach that the teacher chose to use was very dependent on the purpose of the lesson.

\subsection{Inquiry-Based Science}

One of the main goals of science education is to nurture students' scientific dispositions, develop their capability to engage in scientific inquiry, and teach them how to reason scientifically (National Research Council [16]. The four essential elements in any science education program, Osborne [17] argues are: (a) The conceptual, which builds students understanding of the knowledge and ideas of science; (b) the cognitive, which promotes students' ability to reason critically and scientifically; (c) the nature of science, which focuses on how scientific knowledge is produced and what makes it reliable; and (d) the social and affective, which are designed to promote intellectually engaging experiences. Moreover, Osborne argues that "dialogic enquiry is central to learning as it demands the use of epistemic processes-describing, explaining, predicting, arguing, critiquing, explicating and defining" (p. 180). When students have opportunities to engage in cooperative scientific inquiries, they learn to listen to what others have to say, ask and refine questions, debate ideas, make predictions, plan and undertake investigations, use a variety of tools and artefacts to collect and analyze data, and communicate their ideas and findings to others [18-20].

Kang and Keinonen [21] investigated the effect of four student-centered approaches on students' interest and achievements in science. The authors used a large-scale dataset derived from the Program for International Students Assessment (PISA) 2006. The four approaches to teaching that were assessed were relevant topic-based, open- and guided-inquiry, and discussion-based approaches. The results demonstrated that relevant topic-based approaches and guided inquiry-based learning were strong positive predictors for students' achievement in science and they were also positively associated with students' interest. In contrast, open inquiry-based learning and discussion-based learning were strong negative predictors of students' achievement and interest in science. Kang and Keinonen 
concluded that students become more interested in science when they have opportunities to participate in more guided-inquiry learning where connections are made between what they are learning in school science and their real-life experiences and it is this increased interest in science that accounts for better achievement outcomes.

One approach to teaching inquiry that adopts a guided-inquiry approach is the 5Es model of inquiry instruction [22]. In this instructional model, students are provided with opportunities to participate in learning tasks that arouse their curiosity, challenge their conceptions or misconceptions, explore potential solutions, and re-organize and re-construct their current knowledge and understandings to develop explanations, based on the evidence they derive from their own investigations. The advantages of this approach to inquiry learning is that it taps students natural desire to learn how the world works and provides a structure for understanding the nature and development of scientific knowledge and how it is practiced through learning experiences that are meaningful to the learner [18,23]. In this way, students learn how to represent ideas, use scientific tools, and interact appropriately with peers in their cooperative, inquiry science groups in the classroom [24,25].

\subsection{Purpose of the Case Study}

Given that many teachers face challenges in teaching students how to engage in discourses about scientific issues, identify and question scientific claims, and draw evidence-based conclusions about problem-based issues, the purpose of this case-study was to investigate how one exemplary Year 6 teacher taught two inquiry-based science units from two units in the Australian Curriculum-Science (ACARA, 2011). A case study design was chosen as it enabled the researcher to provide an in-depth exploration of an individual teacher's approach to teaching inquiry-based science to her students [26]. In particular, the case study focused on how she used different discourses to capture students' curiosity in the inquiry-based tasks and provided opportunities for them to investigate different topics together to develop explanations for what they observed. The study also investigated the language that the students used as they worked on the different inquiry-based tasks across Lessons 1-6.

\section{Method}

\subsection{Context for the Study}

The case study reported here is part of a larger study involving eight Year 6 teachers from three schools in Brisbane, Australia. All teachers had agreed to teach two units from the Australian Curriculum-Science (ACARA, 2011) for once a term for two consecutive school terms (see [24]). The case study teacher was one of four teachers who were identified as very effective teachers, based on indicators of teacher effectiveness adapted from the research on teacher effectiveness in teaching science, the Australian Professional Standards for Teachers developed by the Australian Institute for Teaching and Learning (AITSL) and previous research by Gillies [27-29] on the effects of cooperative learning on students' task behavior, language, and learning. All teachers were videotaped for approximately one hour for each of the six, inquiry-based science lessons across the two inquiry-based science units. Two groups of students in each teacher's classroom were also videotaped as they worked on their small group activities.

All teachers in the larger study [24] had participated in three days of professional learning workshops that provided them with the background information on the two inquiry-based science units from the Biological Science and Earth and Space Science strands of the Australian Curriculum-Science. As this curriculum has a focus on teaching through inquiry, emphasis was given to ensuring that teachers were introduced to the 5Es model of inquiry [30,31], the importance of students working cooperatively [32], and the importance of dialogic approaches (i.e., Exploratory Talk) for promoting interactions and learning in science [28,33]. 


\subsection{Measures}

\subsubsection{Teacher Language}

An observational schedule that coded the teacher's use of scientific language was used in this study. The six categories of language that were identified and coded according to frequency included: (a) Making basic statements where the teacher presents a specific point of view or presents facts; (b) asks an open question, which is designed to elicit information; (c) asks a closed question such as an initiation-response-evaluation question or a short answer response; (d) mediates students learning through challenging and scaffolding their thinking; (e) encourages students efforts or ongoing engagement with the task; and (f) uses maintenance language designed to ensure the resources needed to complete the task are available. Teacher language was coded from the observational schedule that was developed for the larger study by Gillies and Baffour [24]. The teacher was videotaped for approximately one hour for the six inquiry-based science lessons across two school terms. All video data were coded by three research assistants who were trained teachers, with two being science teachers, and all had had extensive experience coding video data (inter-observer reliability for the frequency of the six language categories ranged $94-96 \%$ ). In addition, all video data were transcribed enabling the identification of language that was authoritative and interactive or dialogic and interactive [13]. Authoritative and interactive language is characterized by the teacher leading the students through a series of questions and answers with the aim of reaching a clear understanding of the topic under investigation (discussion occurred between the two research assistants who were science teachers on the authoritative/interactive and the dialogic/interactive language categories until $100 \%$ agreement was achieved). In the authoritative and interactive approach, the teacher and students take turns discussing an issue with various voices not taken into account as attention is focused on one perspective [14]. Dialogic and interactive language is characterized by the teacher seeking to elicit and explore the students' ideas about a particular topic by asking questions that probe students' points of view [12]. Dialogic and interactive language involves the teacher and students taking turns to express ideas or comment on an issue with different voices represented and taken into account [14].

\subsubsection{Student Language}

Five categories of student language were coded during the group activities, based on research by Gillies et al. [24] that identified the types of language students use during inquiry-based science activities and included: (a) Social language (students provide directions, affirm support, suggest solutions, and negotiate actions to take); (b) basic statement (share information, brief statement on everyday knowledge); (c) basic scientific language (correct use of scientific terms and contributes an idea with reason); (d) moderate scientific language (evidence based on conceptual knowledge, strategy to verify information); and (e) advanced scientific language (cites evidence to speculate, reason, challenge others' propositions, negotiate meaning). Video data of the two groups of students were also coded for frequency by the three research assistants (as mentioned above). Additionally, each lesson was fully transcribed, enabling the identification of language that involved the students providing relevant information to the group, utilizing the correct scientific language, and contributing ideas and information that were based on their conceptual knowledge and understandings.

\section{Results and Discussion}

Table 1 presents the total percentage of teacher language categories used during the six inquiry-based science lessons. While the teacher used all six categories of language across the six lessons, it was apparent that the language used in each lesson was very dependent on the type of inquiry-based task the students were expected to complete. For example, in Lessons 1 and 2, the teacher asked more open questions and mediated language as she challenged the students to link their understandings of earthquakes to the task they were undertaking. In contrast, in Lesson 3, the students were working more independently in their small groups to construct an earthquake 
proof building so the language the teacher used involved more mediation and maintenance where she challenged and scaffolded their thinking and assisted the students with any technical problems or resources they needed to complete this task. In Lesson 4, the students were working together to construct sentences using as many words as they could from their 'word wall' on Infectious Diseases. In this lesson, the language involved the teacher making more basic statements and using language that had a maintenance focus.

Table 1. Percentages of teacher language used during the six inquiry-based science lessons.

\begin{tabular}{ccccccc}
\hline Lesson & $\begin{array}{c}\text { Basic } \\
\text { Statement }\end{array}$ & $\begin{array}{c}\text { Open } \\
\text { Question }\end{array}$ & $\begin{array}{c}\text { Closed } \\
\text { Question }\end{array}$ & Mediates & Encourage & Maintenance \\
\hline $\mathbf{1}$ & 14 & 33 & 10 & 30 & 1 & 11 \\
\hline $\mathbf{2}$ & 13 & 26 & 14 & 23 & 7 & 16 \\
\hline $\mathbf{3}$ & 13 & 5 & 10 & 24 & 9 & 39 \\
\hline $\mathbf{4}$ & 27 & 1 & 16 & 11 & 8 & 37 \\
\hline $\mathbf{5}$ & 26 & 7 & 11 & 21 & 15 & 20 \\
\hline $\mathbf{6}$ & 32 & 36 & 16 & 1 & 5 & 10 \\
\hline
\end{tabular}

Lesson 5 began with a video on bacteria, followed by a discussion about how bacteria are important. In this lesson, the teacher focused on providing basic information, mediating students' thinking and learning, and ensuring that students had the assistance and resources needed for the task. Finally, Lesson 6 was a role play by the teacher where she pretended that she had contracted a disease and the students who were "doctors" had to deduce what that disease was on the basis of the research they had done previously on diseases and the clues she provided in the role play. The language that the teacher used involved predominantly making basic statements and providing factual information and asking open questions as the students worked on resolving this dilemma.

Table 2 presents the total percentage of student language categories used during the six inquiry-based science lessons. As with the teacher language, it was apparent that the language used in each lesson was very dependent on the type of inquiry-based task the students were expected to complete and the language the teacher had modelled prior to the small group tasks. For example, in Lesson 1, the students were engaged in determining the magnitude of an earthquake so $90 \%$ of the total language involved the students providing assistance by making basic statements (facts relevant to the topic) and using basic and moderate scientific language. Certainly, over $60 \%$ of the teacher's language in this lesson had involved asking open questions and mediating the students' thinking and learning so they were 'attuned' to the importance of synchronizing with each other and providing appropriate information and assistance as needed to complete the task.

In Lesson 2, the students were focused on constructing a gum drop and testing its strength and stability so they were predominantly using social language where they offered support and suggestions to each other and used basic scientific language, which involved contributing ideas and requesting explanations. The teacher's language during this lesson mainly involved asking open questions and mediating the students' thinking and learning; language that promoted student engagement with the task.

The students were certainly engaged with constructing an earthquake proof building in Lesson 3 , so a considerable percentage of their language interactions were social as this was a hands-on activity with the students making suggestions on how to stabilize and brace the building. The teacher's language in this lesson involved challenging and scaffolding the students thinking (mediating) and making comments designed to ensure the students had the technical assistance and resources needed to complete the task. 
Table 2. Percentages of students' language used in their science groups during Lessons 1-6.

\begin{tabular}{ccccccc}
\hline Lessons & Groups & $\begin{array}{c}\text { Social } \\
\text { Language }\end{array}$ & $\begin{array}{c}\text { Basic } \\
\text { Statement }\end{array}$ & $\begin{array}{c}\text { Basic } \\
\text { Science }\end{array}$ & $\begin{array}{c}\text { Moderate } \\
\text { Science }\end{array}$ & $\begin{array}{c}\text { Advanced } \\
\text { Science }\end{array}$ \\
\hline $\mathbf{1}$ & Group 1 & 10 & 39 & 27 & 24 & \\
\hline $\mathbf{2}$ & Group 1 & 33 & 18 & 42 & 7 & \\
\hline $\mathbf{3}$ & Group 2 & 33 & 5 & 56 & 2 & \\
\hline & Group 1 & 54 & 1 & 44 & 6 & \\
\hline $\mathbf{4}$ & Group 2 & 77 & 7 & 10 & 1 & \\
\hline $\mathbf{5}$ & Group 1 & 36 & 51 & 12 & 3 & 15 \\
\hline $\mathbf{6}$ & Group 2 & 21 & 66 & 11 & 1 & 33 \\
\hline
\end{tabular}

In Lesson 4, the students were engaged in playing a card game that required them to recognize different diseases, their mode of transmission, and how transmission can be prevented. As this was a hands-on activity, the language the students used was mostly social and involved making basic statements about the task while the teacher's language predominantly involved making basic statements and ensuring that the students had the resources needed to complete this activity (maintenance).

Lesson 5 began with the teacher showing a short video on different types of micro-organisms and discussing how they affect people. In this instance, the language used by the groups involved making basic statements to facilitate completion of the task with the teacher using a combination of making basic statements, asking open question, mediating the students' thinking and learning, and maintenance language.

Finally, Lesson 6 involved a role play with the students tasked with identifying the 'disease' the teacher had caught on her holiday. One hundred percent of the student language in both groups involved the use of scientific language as the students worked to resolve the problem scenario.

\subsection{Teacher-Student Language Interactions during Lesson 1-6}

Lesson 1: The teacher is recapping on the information from the students' previous lesson on earthquakes and the investigation they are going to do in their groups on identifying the magnitude and location of earthquakes using a Richter or modified Mercalli scale. The vignette below represents a few minutes of the teacher and students discussing the investigation that the students will be undertaking in their small groups.

1. T: OK... meaning what? That's not very close to tectonic plates what are your thoughts- what are you saying? (Open question)

2. S: I reckon we didn't hear about it because we're on the other side of the country and because we're on one side of the country so there's no need to worry then, because it's a different part of the country and a different state. (Explanation)

3. T: OK, alright, point taken. (Encourager) And last one, Billie?

4. S: I think because when they find out when the earthquakes actually happen you don't feel it in one spot. They feel it from around the areas and then they figure out where the earthquake is. (Explanation)

5. T: Right. interesting, interesting. OK. So we take all that information with us, have a look here; let's have a look at this map a little bit deeper now. And let's see if we, we change our minds on 
any of those facts. Last $4 \mathrm{~h}$ would be red, last $24 \mathrm{~h}$ that orange colour, and we can see one here, and then other. So, those others have to be within those last 7 days though (Mediates)

6. S: Can they say magnitude? (Closed question)

7. T: No, sorry, yes. This here is our magnitude. So you'll be able to have a look at your computers later on, but you've got the size of the dot. So if I can have a look at some of those smaller dots, smaller Richter on the-smaller magnitude. OK? The larger dots are going to have the larger magnitude. And the most awesome part about this website, I just was very excited, I never knew it even existed! If I go and click on one of these, let's go to this one here that's happened in the last $4 \mathrm{~h}$, the last $24 \mathrm{~h}$ sorry? (Mediates)

8. S: Does it show a video? (Closed question)

9. T: No, it doesn't show me a video. But what it does do, it takes me to where it is, yes, OK, it tells me the magnitude- $5, \mathrm{OK}$, the depth of it, $96 \mathrm{~km} .$. now, I want you to think about that depth and remember it later on. As a researcher-when you're researching, see if that makes a difference. 96km. (Mediates) Let's have a lookie here. So, this happened at—what time, if it's 22:15? 22:15, come on, put our maths brains on.

10. S: $10: 15 \mathrm{pm}$

11. T: OK? 10:15 pm. Let's go into estimated shaking and damage. Do you think a magnitude of-a magnitude of 5 is going to give much damage? (Open question)

12. S: Not a lot...

13. T: You're saying no- yeah- some? So you're thinking, thinking? OK. Let's have a look. And you'll see this red here, this information has not been finalised yet because they're obviously doing more and more, um, investigations of it first. Is estimated this earthquake could have been felt $169 \mathrm{~km}$ away and that circle shows you. It could have caused damage up to $13 \mathrm{~km}$ away. So, they would have felt it right down here. OK? They're saying it happened here... what do I say where I-it's, it's happened? What do I call that spot just there? (Mediates)

14. S: Epicentre

15. T: Epicentre. OK. So they're saying this is where the location of it was. But they're saying they could feel it right down here as well. OK? So $169 \mathrm{~km}$ away. The damage could have been felt $13 \mathrm{~km}$ away from it. So when you go into this one, it is a great website to go in, just have a look and look at all the little bits of information. Um, this is where.... now. The following map shows the location of the stations that detect this earthquake. How could a station down here feel that earthquake? How could that be possible? And that's my question for you today. How could these-this station down here, find out these scientists know that earthquake happened right up there. How could they have felt that? OK? How did they sense that? How did they know? They didn't actually feel the ground shaking right down there. OK, because it's way more than $169 \mathrm{~km}$, you're actually going to do some more exploring there (Mediates).

In the interaction above, it is interesting to note how the teacher is guiding the discussion using a combination of authoritative and interactive discourse [13] where she is focusing on consolidating the students' understanding of earthquakes and some of the terms, such as tectonic plates, magnitude, and epicenter, that they are likely to encounter in their small group discussions. It is interesting to note that of the eight turns initiated by the teacher, two involved open questions and five were designed to encourage thinking. All were followed by the students elaborating on the information (providing an explanation) or generating a closed question or short answer response, indicating that the students were attending to the discussion topic. An examination of Table 1 shows that approximately $66 \%$ of the language that the teacher used during this lesson involved asking open questions and mediating the students' thinking, language designed to promote discussion and learning.

The following is an example of the discussion that one group had on earthquakes, seismographs, and $\mathrm{S}$ and $\mathrm{P}$ waves (forces) that follow an earthquake. 


\section{Students interactions in a cooperative group during Lesson 1}

1. S2: Right! Next part is how do scientists measure the size of earthquakes? They use seismographs reporting... Do you want to see a picture? Come on. That was the seismograph and that was, this is doing the heartbeat. (Explanation)

2. S3: Oh yeah, I saw that picture I was doing a questionnaire for ... Okay, so next person is, I'm going. Okay, you do the first question, Ashley you can do the second question.

3. S4: Okay. So I wrote... Scientists know there'll be another earthquake in the future and scientists try in many ways to predict earthquakes (Explanation)

4. S2: And what are those many ways? (Open question)

5. S3: So that just explains your question. Can scientists predict earthquakes? No, and it is unlikely that...

6. S4: No. It's unlikely scientists will ever predict (Explanation)

7. S3: Seismograms can help locate where the earthquake happened. If they're seconds between hearing or feeling the earthquake you're sure then you know it's close. So that means if you feel the earthquake quite quickly that means you're close to the earthquake. If it takes a long time to reach you it would most likely be far away (Explanation). Scientists use a method called,-I don't know how to say it but it's tria...lation

8. S2: Triangulation

9. S3: It helps to find exactly where the earthquake happened ... So I'll show you a picture of it. It's this, so what happens is it locates where you can feel it and then the epicenter is where you all of them part ...(Explanation)

10. S2: Next question

11. S3: Oh, and I've also got one more, the actual one would be: $\mathrm{P}$ waves was the primary waves so like lightning and $\mathrm{S}$ waves are like thunders, so as it says up there, it says that because if the $\mathrm{P}$ waves is like the epicenter, which is like the lightning, which is the epicenter and thunder is like the $S$ wave, which it takes a long time to get to you, so if it takes say three seconds to get to you, the thunders to get to you, you know the earthquake is like quite close to you, I mean..(Explanation)

Although this interaction represents only a few minutes of the group's discussion, over 50\% of their total interactions involved the students providing more details or elaborating on the information under discussion. In short, they were actively attending to the discussion and this is reflected in the scientific language the students used. An examination of Table 2 indicates that $90 \%$ of the language the students used in the lesson involved productive scientific talk where the group members provided relevant information, utilized the correct scientific language, and contributed evidence, based on conceptual knowledge and understandings.

Lesson 2: The purpose of this lesson to plan and test out how braces affect the strength of different shapes. The lesson began with the students watching a short video on how to construct a building and the different types of support that were needed to stabilize it.

1. T: They found it was too wobbly, square and rectangle .... OK, what Jordan suggested, needed that extra triangle across ... OK, so what did you notice? What did you notice, how did-what did they have to go through, what stage did they have to go through to be able to go "this is what-how it's going to work best"- -Tatiana? (Open question)

2. S: They had to plan (Explanation)

3. T: They had to plan it out together, how did they plan? How did they plan? Everyone-one person was control? No, everyone contributed, yep. What else happened? Quinn? (Open question)

4. S: They tested to see what would work. (Explanation)

5. T: Yep, did a bit of testing. Found out some things that weren't going so well. What did they do then, then? If it wasn't going so well? (Open question) 
6. S: They had a few more ideas like adding more poles and stuff in? (Explanation)

7. T: Excellent. (Encouragement) Can you now see if you have a look at your tabs in your technology folder which section they would be up to? What section when they-when things weren't going so well ... ? (Open question)

8. S: Ideation?

9. T: Ideation? Further along. Produce- they had to produce it. And then what was the last one? (Closed question)

10. S: Evaluation

11. T: Evaluation. So they evaluated it wasn't working so well and then they had to go back to the producing stage. That's exactly what you're going to do. They didn't write it down, but at different times you're going to have to write down when you're producing, you're going to have to go, ooh, I'm going to evaluate this, this is not working. OK? And you would write down how you're going to make-what changes you're going to make. That's what they did. OK? They did that process but with a chair. You're going to do it with a building. Alright? So we also noticed-what was the strongest shape? How did they make it stronger? (Closed question)

12. S: Triangles (Explanation)

13. T: They had to go with that triangles.

The teacher, again, is guiding the discussion but, in the vignette above, the language is more dialogic and interactive where the teacher and students together consider different ideas. Of the seven turns initiated by the teacher, four were open and two were closed questions and all were followed by either short answer responses or explanations, indicating that the students were actively engaged in the discussion. In fact, an examination of Table 1 shows that $50 \%$ of the total language that the teacher used consisted of open questions and mediation, language designed to challenge and scaffold the students' thinking.

Students interactions in a cooperative group during Lesson 2 (The students were constructing a gum drop dome and evaluating its strength and stability)

1. S2: Okay, the first question is, someone can do the next question, [reads] why do you think the gum drop dome worked? Explain in terms of pushes and pulls. Okay

2. S1: Because, first it always stick very well to the toothpicks (Explanation)

3. S2: Pushes and pulls, something that has to do with pushes and pulls (Prompts)

4. S4: I got one. Oh, I reckon it didn't hold as well because this falls in the middle (Explanation)

5. S2: No, why do you think they worked? (Open question)

6. S4: Oh, because of the triangles, they've got supporting stuff at the bottom (Explanation)

7. S1: push and pull factor (Explanation)

8. S4: Yeah

9. S3: I'll just move this over here.

10. S4: Okay, Quinn

11. S3: I've got nothing yet

12. S2: Okay, well I think they worked because the dictionary's pushing down on this first thing but the triangles ... (Explanation-referring to the ability of the dome to withstand the pressure of the weight of the dictionary)

13. S1: They had extra support when it came to this

14. S2: Yeah, the triangles allowed extra support when it came down it just didn't collapse as much (Explanation)

Constructing a gum drop dome (see Figure 1) to learn how the different geometric shapes contributed to its stability and strength was certainly an activity that engaged the students' attention and challenged their thinking. Of the 14 turns in the above vignette, 6 involved explanations or reasons 
why the dome was able to withstand the different forces. This pattern of interaction was repeated across the two student groups that were videotaped with over $66 \%$ of the language used identified as productive scientific talk.

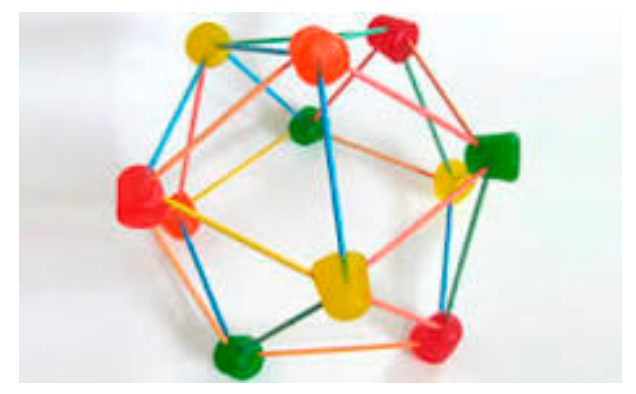

Figure 1. Gum drop dome.

Lesson 3: The purpose of this lesson is to have the students plan and construct an earthquake proof building using the different bracing techniques that they have been learning are used. The lesson began with the teacher recapping on the importance of designing a building that would withstand the different forces unleashed in an earthquake, the strength of the materials needed, and the types of bracing that they needed to consider. In the vignette below, the teacher is moving around the groups to check on their understandings of the task and scaffold and challenge the students' thinking on how they can manage this task.

1. T: That's right, the pressure goes to these particular spots. If you have no corners the pressure is spread out evenly around the whole shape. Okay so that's why a circle can handle it, the cylinder could handle more pressure because it didn't have any corners taking ... the corners, corner places were taking pressure. Okay, so that's what's crushing. (Mediates)

2. S: What about if we didn't, like, sticky tape it together and there was just like a paper cylinder with no sticky tape anymore?

3. T: Then it is going to fall apart, yeah. A cylinder has to be stuck together to be able to make it stay, so yeah, you could. Are you thinking about using a cylinder in yours somewhere? (Mediates)

4. S: (inaudible)

5. T: Yeah, okay, keep going then. So write down little answer there if that was your question. (Maintenance)

6. T: Have you answered all your questions have we? Or are all your inquiry questions answered? You're done? Okay, let's have a look at some of them and what were some of yours Trey? (Maintenance)

7. S: (inaudible)

8. T: Okay so you've already agreed as a group cause you're going to go with the pyramid style? Yep, okay. (Maintenance)

9. S: Not really

10. T: Not really? Okay, what reinforcements are you thinking?(Open question)

11. S: Cardboard, tape and cardboard strips.

12. T: Okay, awesome. (Encouragement) Hang on, I'll just let these guys know. I'll come back to you.

13. T: Okay guys you're in your last two minutes. (Pause) Keep going. Don't let me stop you. (Maintenance)

14. S: How do we use the reinforcement by diagonally, by di, by diagonally, I don't know how to say it, by diagonally placing them on the poles, ah the strips?

15. T: Okay so you're going to have braces, is that what you are talking about? You're going to have bracing? Okay? What was one of your questions Jamie? Did you guys all come up with the same questions at the very beginning? Did you? Oh, okay. (Mediates) 
The teacher's language in the above vignette is more authoritative and interactive because of the nature of the task that the students are completing in their small groups. In fact, 4 of the 15 turns involve the teacher providing basic information or re-affirming the groups' decisions. An examination of Table 1 indicates that this is consistent with the language the teacher used in Lesson 3 with the teacher engaging in more maintenance language designed to help the students continue working on the activity in conjunction with language designed to scaffold and challenge their thinking.

\section{Students interactions in a cooperative group during Lesson 3}

In the vignette below, the students are discussing how they would brace a building (Figure 2) to ensure it would withstand an earthquake. This activity followed immediately on the class discussion that the teacher had with the students in Lesson 3 about planning and designing a model of an earthquake-proof building. The students are using their previous understandings of different shapes, structures, and the strength of different bracing techniques in the construction of this building. The students will be able to test their construction during a simulated earthquake.

1. S3: How will you make it strong?

2. S1: How will we make it strong?

3. S2: By using cross-bracing and sheer walls (Explanation)

4. S3: The crosses and all that sorta of stuff ... How will we construct each layer? (Explanation)

5. S1: With like those four pieces of paper (Explanation)

6. S3: What type of area?

7. S2: Area

8. S3: Area is it in?

9. S2: Well we haven't worked that out yet so just any area

10. S1: Just like...

11. S2: In Alltown (Explanation)

12. S1: Yeah, just in a town because they say it was in a town, didn't they?

13. S3: Will each layer increase in strength?

14. S1: Well it should, because each layer is going to have more weight on it. And we should have more cross braces and stuff (Explanation)

15. S2: Ok. I've got none. I don't have any

16. S1: Yeah you do, which is stronger, a triangle or an arch?

17. S2: But we already know that

18. S1: Well then an arch is stronger, isn't it? (Explanation)

19. S3: An arch is stronger.

20. S1: I said that first

21. S2: Well I already knew that.

The students certainly enjoyed this hands-on activity of designing, constructing, and testing out the viability of their building. All three members of the group contributed to the activity by either asking questions to clarify their understandings or providing explanations to help each other understand the basic science of bracing. An examination of Table 2 shows that this pattern of interaction was consistent across the inquiry-based science lesson for this group. However, the second group (vignette not included) did not demonstrate this type of language interaction. In fact, $77 \%$ of this group's language was socially orientated with members directing the actions of the group or making suggestions about actions to take; ways of interacting that demonstrated that they were actively involved in the task. 


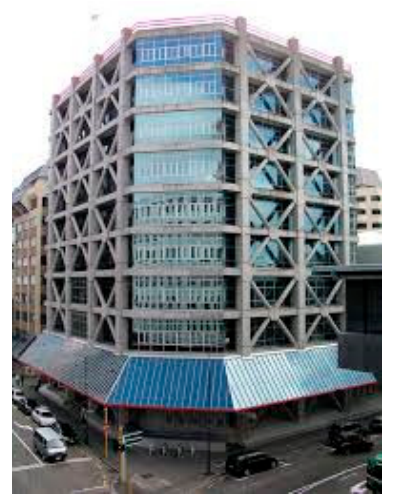

Figure 2. Bracing on building in Christchurch, NZ after an earthquake.

Lesson 4: The teacher is encouraging the students to work together to construct sentences using as many words as they can from their "word wall" on Infectious Diseases (new science unit of work). Terms such as bacteria, organisms, pathogen, disease, infection, and vaccination are some of the words the students will be using in the sentences they construct. In this lesson, the teacher moves around the groups, helping students, clarifying technical terms, and reminding groups to share their knowledge.

T: Everyone's going to have that knowledge, that's right. OK? So I want you to have "knowledge epidemic", and then I want you to, on the next line, write the short version of the date for me. Because we're going to add to our knowledge epidemic page throughout this unit. Now cast your eyes over to our word wall ... I've put up some of the words that we've been looking at this week. Infectious, pathogen, bacteria, antibodies, vaccination, disease, microbe ... I want you to see if you can put those words into a sentence that makes sense. You could use all of them; you could make a couple of sentences ... Just show me that you're kind of having - showing me what knowledge you've gained so far this week. It could be a sentence about a patient. It could be a sentence about a- a factual sentence. It could be a made-up-we've been reading stories about people who have infectious diseases. So you could ha- give a person a name. And have a character in your sentence. It's up to you how you write it. $\mathrm{OK}$, it might be $\mathrm{t}-\mathrm{um}$, telling somebody about your illness, or something like that. How you choose to write it is up to you. You may not get all the words into your sentence. But give it a go. See how many words you can make in your sentence that would make sense ... Go. (Encourages thinking). The teacher then moves around the groups to assist students with their inquiries.

The language the teacher uses in this lesson is more authoritative and non-interactive as over $60 \%$ of her language involved making basic statements and language that included assisting students to resolve problems or continue to work on their current activity (maintenance language) (See Table 1). With this type of interaction, the teacher is presenting a specific point of view; in this case, she is recapping on the information collected on the word wall and directing the students to use that information to construct their sentences.

Students interactions in a cooperative group during Lesson 4 (the students are playing a card game on the different types of infectious diseases)

In the vignette below, the students are constructing sentences about different infectious diseases that they have been studying. They have been learning that infectious diseases are disorders caused by organisms such as bacteria, viruses, fungi, or parasites. While many of these organisms live in and on the human body, they are usually harmless or even helpful. However, under certain conditions, some organisms may cause disease. Some infectious diseases can be transmitted from person to person while others are passed on by insects or other animals. Consuming contaminated food or water is another way in which infectious diseases can be transmitted. The students have been learning that many of these infectious diseases have signs and symptoms, depending on the organism responsible for the infection. In the activity below, the students are working together to construct sentences 
that provide information about the different terms (i.e., infectious, pathogen, bacteria, antibodies, vaccination, disease, microbe) that they have been learning about in their science unit on Diseases.

1. S3: So, this is meningitis, so go down to you meningitis thing. (Direction)

2. S2: Meningitis, where's that?

3. S3: And tick, you've got to tick (Direction)

4. S1: Don't you need to put another card down with this one?

5. S2: No

6. S3: No, just do this first, you've got to tick, on the symptoms you've got to tick inflammation of the spinal cord or brain (Direction)

7. S1: Where's that?

8. S3: That one (Direction)

9. S2: It's the big box (Direction)

10. S3: Yeah the big one, on the symptoms. Yeah, and then also attacks, and form of transmission is water so tick droplets and then for control, tick (Explanation)

11. S1: Tissues

12. S3: Tissues?

13. S1: Tissues and vaccination

14. S3: What does it mean by tissues though?

There is no doubt that the students in the vignette above are focused on the task as they pose questions and provide directions to help complete the task. An examination of Table 2 indicates that this pattern of interaction is consistent with the language the students in both groups used in Lesson 4 where over $50 \%$ of the language involved students responding with basic information to others' questions.

Lesson 5: The students have just finished watching a short video clip on different types of good and bad bacteria. Terms such as bacteria and viruses are microorganisms, symptoms of the Ebola virus, immunization, transmission, toxin, and yeast infection are discussed as the teacher helps the students to recap on information they have learned in previous lessons.

1. T: A yeast infection? You do that with your group first, OK? And then decide where to put it through. OK, so it's not a talking time yet, you're writing any facts you can and put it onto your chart. OK? And then we'll see how much they compare to each other. Off you go. (Mediates)

2. T: Yep, so if it's, if it's an evil one? Yep, produces toxin, good, you put it there. OK, so what's something you wrote down there, Dylan? (Closed question)

3. S: Um ... there's good and bad bacteria.

4. T: Good and bad bacteria, so where would we put that one? (Mediates)

5. S: Um ... in between?

6. T: Yeah, I'd put it, even with the bacteria. On that word itself.

7. S: <inaudible>

8. T: Yeah, put it with the bacteria section. Ashley, what have you got? What did you? No, but tell me something that you learnt on that video, that you didn't know beforehand. (Mediates)

9. S: Um, that ...

10. T: Where are some bacteria found? (Closed question)

11. S: In food

12. T: What food? (Closed question)

13. $\mathrm{S}:<$ inaudible>

14. T: What food were they talking about at the end? They said there's good bacteria found there. (Open question)

15. S: Yoghurt? 
16. T: Yoghurt! OK, so yoghurt can be ... where will it fit? (Closed question)

It is interesting to note that over $30 \%$ of the language used in this vignette involves the teacher challenging and scaffolding the students' learning. This pattern is consistent with the language the teacher used across the full lesson when she provided basic information, mediated students' learning, and encouraged ongoing involvement in the task (see Table 1). In this sense, the language used was dialogic and interactive as she encourages the students to investigate different ideas while simultaneously challenging and scaffolding their learning.

\section{Students interactions in a cooperative group during Lesson 5}

In the vignette below, the students are writing sentences about the different types of good and bad bacteria and where they are found (Figure 3).

1. S3: Okay, Anna what's what you said? (Open question)

2. S4: Some bacteria help us (Explanation)

3. S3: How? Did you write how? (Open question)

4. S4: No

5. S3: What did you write? (Closed question)

6. S1: Bacteria is important because it can kill viruses (Explanation)

7. S2: Sometimes ... No copying Dean

8. S1: Is that correct? (Closed question)

9. S3: I don't know

10. S2: No. Only sometimes

11. S3: What did you write? (Open question)

12. S2: I've only got this one: Bacteria is important because it sometimes helps you and maybe provides stuff for us (Explanation)

13. S3: Yeah, but you need to write how

14. S1: Yes

15. S2: Because it provides stuff for us

16. S3: What stuff? (Open question)

17. S2: I'm not sure

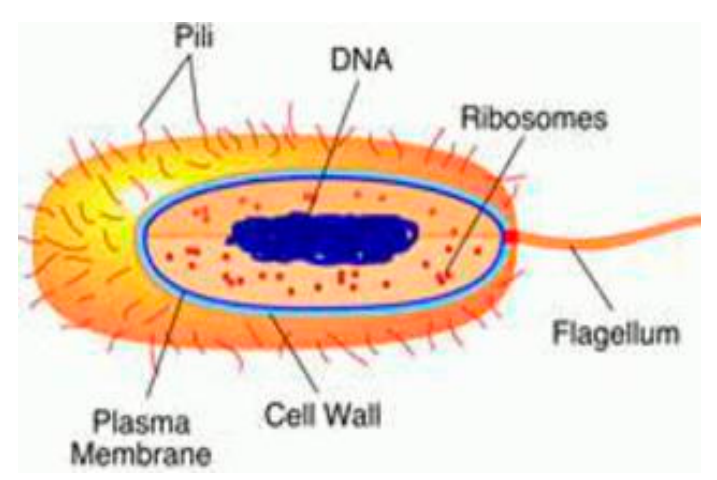

Figure 3. Single-cell bacterium.

Here is no doubt that the students in the above vignette are synchronized with each other as they ask and respond to questions. In fact, two of the responses provided reasons or explanations as to why some bacteria are important. An examination of Table 2 indicates that during this lesson, the students predominately responded with brief statements, based on what they had been learning.

Lesson 6: The teacher has just finished a role play where she told the class she went to Nepal and while she was there, she contracted a disease. The students have been studying different diseases and 
the effects they have on people so they are about to begin working in their small groups to deduce the name of the disease, based on the clues the teacher has provided.

1. T: Have you got why, what have I got? And have you got why it's definitely that? Can you choose a disease and tell me why it's not definitely something else. You've got to justify, you've got to say why it is and why it's definitely that and choose another one and say it's definitely not this because ... ? (Open question)

2. S: Malaria [inaudible] mosquitoes .... .

3. T: Why not cholera? (Open question)

4. S: smallpox

5. T: Mmmmm have you written that down. Ok you have to be able to prove to me ok? (Basic statement)

6. T: [new group, listens for a moment] Oh! really? I think I'm this. Why? (Open question)

7. S: because when you had your itichy ... when you have malaria it spread through the mosquitos and the parasites and all. So you were in a tropical area,

8. T: What about HIV? (Open question)

9. S: You wouldn't have HIV because that...

10. S2: It doesn't show up like straight away and you don't have

11. S1: any symptoms like the vomiting and that?

12. T: You guys need to start to write down what you think it is and give me reasons and what it's definitely not and you've just been talking about it. Why is it not HIV, why is it not cholera and why is it not smallpox. Ok you've got to write those things down. (Mediates)

13. T: Doctors, I just want to warn you that you have to have what it is and why. Why it's not that disease, why it's not that disease and why it can't possibly be that disease [counting off on fingers] So four parts to your summary before you give it to me cause otherwise I won't believe you. I'll think oh great doctor this is, ok. So you've really got to be to convince me that this is my illness. (maintenance)

The language the teacher used in the above vignette was certainly shaped by the role play she had presented as the students' task was to identify the disease she had contracted while holidaying in Nepal. She keeps reminding the students that they had to be able to indicate 'why' they have decided it is a certain disease and be prepared to 'justify' their choice. The students are certainly 'tuned-in' to the teacher as every question or statement involves a student providing a reason, explanation, or short answer response. An examination of Table 1 indicates that over $60 \%$ of the teacher's language during this lesson involved her in making basic statements (about the task) and asking open questions. The language used was authoritative and interactive as she encouraged the students to think carefully about the disease that they chose, provide reasons for their choice, and be prepared to discuss why they eliminated other diseases.

\section{Students' interactions in a cooperative group during Lesson 6}

In the vignette below, the students are discussing the possibility that the disease the teacher contracted was malaria.

1. S3: Well, I'm doing Malaria

2. S2: Malaria is transmitted by....

3. S3: Malaria is transmitted by [inaudible] on mosquitos (Explanation)

4. S2: What?

5. S3: Mosquitos

6. S2: Bitten by mosquitos (Explanation)

7. S3: Yeah, you get bitten by mosquitos 
8. S2: I have no idea what you're saying... too loud

9. S3: It gives you aids

10. S1\& S2: What??

11. S3: No, no, no, it gives you head-aches [laughs] sorry (Explanation)

12. S1: That was nice \{inaudible], okay?

13. S3: Treatment?

14. S1: How can you control it? (Open question)

15. S3: How can you control it? They control it through the malaria DDT program (Explanation)

While the vignette above represents only a few minutes of the students' discussion, it is interesting to note that they very readily identify that malaria is transferred by being bitten by a mosquito and that it is controlled by a DDT program (an insecticide to control malaria). All three students are involved in the discussion, either through asking questions, responding to them, or providing information or help. An examination of Table 2 indicates that $100 \%$ of the language involved the students in both groups using basic, moderate, and advance scientific language to gain deeper insights of the issue they were investigating. This was the only lesson where the students' utilized all forms of scientific language, clearly indicating that they had developed a clear understanding of the importance of using the correct nomenclature and the role it played in helping them to engage in scientific discussions.

\subsection{Summary of Teacher-Student Language during Lessons 1-6}

In the six lessons outlined above, it is interesting to note how the teacher's language was very dependent on students' previous understandings of the topic and the type of inquiry-based task they were expected to complete. For example, in Lessons 1, 2, and 3 the teacher used more authoritative and interactive discourse where she recapped on the students' technical knowledge of earthquakes while simultaneously posing a series of open questions that challenged and scaffolded their thinking. The students, in turn, responded with more details about the topic, asked closed questions to elicit information, or provided short answer responses; all indicative of students who are motivated and engaged with the task.

It was interesting to note that while the teacher's interactions with the students were essentially authoritative as she began each lesson by introducing the problem and then guiding students towards developing an understanding of earthquakes and the issues of how to brace buildings to manage the various forces they released, there were occasions when her language became dialogical as she encouraged the students to express their opinions and provide reasons and justifications for the positions they had adopted [13]. Similarly, in Lessons 4, 5, and 6 where the teacher again used more authoritative language designed to ensure students understood the specific terms associated with their unit of work on Infectious Diseases. Again, there were occasions when the teacher's language was dialogical as she challenged and scaffolded the students' thinking to engage in more meaningful inquiries about the topics they were discussing. This type of discourse was particularly evident in Lesson 6 where the students had to critique the 'scientific' cues that emerged during the role play and try to reconcile them with their own investigations on infectious diseases to identify the particular 'disease' the teacher had acquired on her holiday in Nepal.

Scott et al. [14] and Aguiar, Mortimer, and Scott [20] maintain that both authoritative and dialogic discourses are necessary with the former enabling teachers to develop the canonical scientific view or ways of reasoning in science while the latter encourages investigation of the ideas presented. When teachers interact with students to share their knowledge and understandings about science and scaffold their thinking, they also interact socially with students, which it is argued helps to keep them engaged in the discussions and motivated to learn science concepts. In short, it is through talking and thinking together that students learn to make connections between everyday ideas and scientific ideas to construct new understandings [34]. 
If students are to engage successfully in science then they need to have opportunities to participate in dialogic exchanges with each other where they learn to express their views about the problem at hand, probe and explore the views of others, and reconcile these views with the scientific perspective [13,35]. Inquiry-based science instruction, Harris and Rooks [25] propose, places higher demands on students in terms of participation, personal responsibility, and cognitive effort than would normally occur in classrooms where teachers use traditional transmission modes of teaching. In inquiry-based learning classrooms, students cooperate to plan and conduct investigations and engage in discussions and debate with each other and the teacher [30-34]. In so doing, students have opportunities to ask and answer questions to help make their thoughts, reasons, and knowledge explicit, learn new ways of using language that they can appropriate for themselves, and make sustained contributions to class discussions; ways of interacting that promote understanding and learning in science [33,34].

\subsection{Limitations}

There are two limitations to this study. First, this is a case study of one Year 6 teacher who taught two units of inquiry-based science across two school terms. While the data presented enabled the author to undertake an in-depth exploration of this teacher's approach to teaching inquiry-based science to her students, the generalizability of the insights gained are limited. Second, because of the constraints that operated around the teacher's class time, there were no pre-intervention measures collected on the students' discourse or reasoning and problem-solving skills during their small group discussions, limiting the interpretations that can be placed on the insights gained. These are issues that need to be addressed in future studies.

\section{Conclusions}

The purpose of this case-study was to investigate how one very effective teacher taught two, cooperative inquiry-based science units to her Year 6 class. In particular, the case-study focused on how she used different discourses to capture students' curiosity in the inquiry-based tasks, provided hands-on activities to enable them to test-out their hypotheses and develop explanations for what they found in order to help them become more scientifically literate and have a broader understanding of the role of science in the world in which they live. The results showed that the students engaged constructively with their peers on the inquiry group tasks; they used the correct scientific language to discuss different phenomena, make claims, and compare findings. Furthermore, they became more adept at expressing their opinions and providing explanations and justifications for the 'scientific' positions they had adopted across the six inquiry-based science lessons; core cognitive practices that support learning. This case study highlights the importance of utilizing both authoritative and dialogic discourse to challenge and scaffold students' thinking to support enhanced understandings and reasoned argumentation during inquiry-based science. This case study fills a gap in the literature on how teachers can utilize different communicative approaches during inquiry-based science units to promote student engagement and learning.

Funding: This research was funded an Australian Research Council Grant: ARC-SRI: Science of Learning Research Centre (project number SR120300015).

Conflicts of Interest: The author declares no conflict of interest.

\section{References}

1. Gillies, R. Inquiry-Based Science Education; CRC Press: Boca Raton, FL, USA, 2020; p. 115.

2. Herrenkohl, L.; Tasker, T.; White, B. Pedagogical practices to support classroom cultures of scientific inquiry. Cogn. Instr. 2011, 29, 1-44. [CrossRef]

3. Chinn, C.; Duncan, R.; Dianovsky, M.; Rinehart, R. Promoting conceptual change through inquiry. In International Handbook of Research in Conceptual Change, 2nd ed.; Vosniadou, S., Ed.; Routledge: London, UK, 2013; pp. 539-559. 
4. Alexander, R. Culture, dialogue and learning: Notes of an emerging pedagogy. In Exploring Talk in Schools; Mercer, N., Hodgkinson, S., Eds.; Sage Publications Ltd.: London, UK, 2008; pp. 91-114.

5. $\quad$ Alexander, R. Essays on Pedagogy; Routledge: London, UK, 2008; p. 212.

6. Wolfe, S.; Alexander, R. Argumentation and Dialogic Teaching: Alternative Peda-Gogies for a Changing World. 2009. Available online: www.robinalexander.org.uk/index.php/publications/ (accessed on 15 December 2013).

7. Boyd, M.; Markarian, W. Dialogic teaching: Talk in service of a dialogic stance. Lang. Educ. 2011, 6, 515-534. [CrossRef]

8. Reznitskaya, A.; Gregory, M. Student thought and classroom language: Examining the mechanisms of change in dialogic teaching. Educ. Psychol. 2013, 48, 114-133. [CrossRef]

9. Gillies, R. Productive academic talk during inquiry-based science. Pedagog. Int. J. 2013, 8, 126-142. [CrossRef]

10. Alexander, R. Developing dialogic teaching: Genesis, process, trial. Res. Pap. Educ. 2018, 33, 561-598. [CrossRef]

11. Howe, C.; Hennessy, S.; Mercer, N.; Vrikki, M.; Wheatley, L. Teacher-student dialogue during classroom teaching: Does it really impact on student outcomes? J. Learn. Sci. 2019, 28, 462-512. [CrossRef]

12. Garcia-Carrion, R.; de Aguileta, G.; Padros, M.; Ramis-Salas, M. Implications for social impact of dialogic teaching and learning. Front. Psychol. 2020, 11, 140. [CrossRef]

13. Scott, P.; Mortimer, E. Meaning Making in high school science: A framework for analysing meaning making interactions. In Research and the Quality of Science Education; Boersman, M., Goedhart, M., de Jong, O., Eikelhof, H., Eds.; Springer: Amsterdam, The Netherlands, 2005; pp. 395-406.

14. Scott, P.; Mortimer, E.; Aguiar, O. The tension between authoritative and dialogic discourse: A fundamental characteristic of meaning making interactions in high school science lessons. Sci. Educ. 2006, 90, 605-631. [CrossRef]

15. Bosser, U.; Lindahl, M. Teachers coordination of dialogic and authoritative discourses promoting specific goals in socio-scientific issue-based teaching. Int. J. Sci. Math. Educ. 2020. [CrossRef]

16. National Research Council. A Framework for K-12 Science Education: Practices, Crosscutting Concepts, and Core Ideas; National Academies Press: Washington, DC, USA, 2012; p. 383.

17. Osborne, J. Science education for the twenty first century. Eurasia J. Math. Sci. Technol. Educ. 2007, 3, $173-184$. [CrossRef]

18. Bell, T.; Urhahne, D.; Schanze, S.; Plotezner, R. Collaborative inquiry learning: Models, tools, and challenges. Int. J. Sci. Educ. 2010, 32, 349-377. [CrossRef]

19. Llewellyn, D. Inquire Within: Implementing Inquiry and Argument-Based Science Standards in Grades 3-8; Corwin: Thousand Oaks, CA, USA, 2014.

20. Aguiar, O.G.; Mortimer, E.F.; Scott, P. Learning from responding to students' questions: The authoritative and dialogic tension. J. Res. Sci. Teach. 2010, 47, 174-193. [CrossRef]

21. Kang, J.; Keinonen, T. The effect of student-centered approaches on students' interest and achievement in science: Relevant topic-based, open and guided inquiry-based, and discussion-based approaches. Res. Sci. Educ. 2018, 48, 865-885. [CrossRef]

22. Gillies, R.; Nichols, K.; Khan, A. The effects of scientific representations on primary students' development of scientific discourse and conceptual understandings during cooperative contemporary inquiry-science. Camb. J. Educ. 2015, 45, 427-450. [CrossRef]

23. Archer, L.; Dewitt, J.; Osborne, J.; Dillon, J.; Willis, B.; Wong, B. “Doing” science versus "Being” a scientist: Examining 10/11-year-old schoolchildren's construction of science through the lens of identity. Sci. Educ. 2010, 94, 617-639. [CrossRef]

24. Gillies, R.; Baffour, B. The effects of teacher-introduced multimodal representations and discourse on students' task engagement and scientific language during cooperative, inquiry-based science. Instr. Sci. 2017, 45, 493-513. [CrossRef]

25. Harris, C.; Rooks, D. Managing inquiry-based science: Challenges in enacting complex science instruction in elementary and middle school classrooms. J. Sci. Teach. Educ. 2010, 21, 227-240. [CrossRef]

26. Creswell, J. Educational Research: Planning Conducting and Evaluating Quantitative and Qualitative Research; Pearson Education Limited: Essex, UK, 2014.

27. Gillies, R. The behaviors, interactions, and perceptions of junior high school students during small-group learning. J. Educ. Psychol. 2003, 95, 137-147. [CrossRef] 
28. Gillies, R. Structuring cooperative group work in classrooms. Int. J. Educ. Res. 2003, 39, 35-49. [CrossRef]

29. Gillies, R. Teachers' and students' verbal behaviours during cooperative and small-group learning. Br. J. Educ. Psychol. 2006, 76, 271-287. [CrossRef]

30. Bybee, R. Enhancing science teaching and student learning: A BSCS perspective. In Proceedings of the ACER Research Conference: Boosting Science Learning: What It Will Take. ACER Research Conference. Review of Educational Research, Canberra, ACT, Australia, 13-15 August 2006; Volume 64, pp. 1-35.

31. Bybee, R. The BSCS 5E Instructional Model: Creating Teachable Moments; National Science Teachers' Association: Arlington, VA, USA, 2015; p. 126.

32. Slavin, R.; Lake, C.; Hanley, P.; Thurston, A. Experimental evaluations of elementary science programs: A best-evidence synthesis. J. Res. Sci. Teach. 2014, 51, 870-901. [CrossRef]

33. Mercer, N.; Dawes, L. The study of talk between teachers and students, from the 1970s until the 2010s. Oxf. Rev. Educ. 2014, 40, 430-455. [CrossRef]

34. Lehesvuori, S.; Ramnarain, U.; Viiri, J. Challenging transmission modes of teaching in science classrooms: Enhancing learner-centeredness through dialogicity. Res. Sci. Educ. 2018, 48, 1049-1069. [CrossRef]

35. Gillies, R. Dialogic interactions in the cooperative classroom. Int. J. Educ. Res. 2016, 76, 178-189. [CrossRef]

Publisher's Note: MDPI stays neutral with regard to jurisdictional claims in published maps and institutional affiliations.

(C) 2020 by the author. Licensee MDPI, Basel, Switzerland. This article is an open access article distributed under the terms and conditions of the Creative Commons Attribution (CC BY) license (http://creativecommons.org/licenses/by/4.0/). 